\title{
Foreign Aid Initiatives and the HIV/AIDS Epidemic in Nigeria: Perspectives on Country Ownership and Humanistic Care
}

\author{
B. N. Joseph ${ }^{1^{\star}}$, C. A. Abimiku² ${ }^{2}$ D. A. Dangiwa ${ }^{1}$, D. M. Umar ${ }^{1}$, K. I. Bulus ${ }^{3}$ \\ and M. L. P. Dapar ${ }^{1}$ \\ ${ }^{1}$ Department of Clinical Pharmacy and Pharmacy Practice, University of Jos, Nigeria. \\ ${ }^{2}$ Department of Economics, University of Jos, Nigeria. \\ ${ }^{3}$ Department of Political Science, University of Jos, Nigeria.
}

\begin{abstract}
Authors' contributions
This work was carried out in collaboration between all authors. Author BNJ conceived the idea/topic designed the study, performed the statistical analysis, wrote the protocol and wrote the first draft of the manuscript. Author CAA reviewed and modified the write-up on the economic aspect of foreign aid funding. Authors DAD and DMU wrote part of the manuscript. Author KIB managed the political aspect of this work. Author MLPD co-ordinated the research process, editorial and manuscript review. All authors read and approved the final manuscript.

Article Information

DOI: $10.9734 /$ ISRR/2017/34538

Editor(s):

(1) Gabriella GD D'ettorre,Department of Public Health and Infectious Diseases, University of Rome "Sapienza" and Azienda

Policlinico Umbertol, Italy.

Reviewers:

(1) Aurora Martínez Romero, Universidad Juárez del Estado de Durango, Mexico.

(2) Ashok Pandey, Public Health Research Society, Nepal.

(3) Ajide Bukola, Bingham University, Nigeria.

Complete Peer review History: http://www.sciencedomain.org/review-history/19626
\end{abstract}

Review Article

Received $31^{\text {st }}$ May 2017

Accepted $16^{\text {th }}$ June 2017

Published $20^{\text {th }}$ June 2017

\section{ABSTRACT}

With a prevalence rate of $3.1 \%$, Nigeria has a generalized HIV/AIDS epidemic. Like much other developing countries, Nigeria has to collaborate with development partners to fight the HIV/AIDS scourge. This review assesses the impact of foreign aid initiatives on the fight against HIV/AIDS in Nigeria. It examines Nigeria's capacity and willingness to independently own a sustainable provision of HIV/AIDS care in the country. This paper assesses the outcomes of the HIV/AIDS scheme. Our review indicates that foreign aid initiatives were responsible for the rapid scale-up in HIV/AIDS services and improvement in morbidity and mortality rates. While foreign aids have

*Corresponding author: Email: josephb@unijos.edu.ng, jbnasara2002@yahoo.com; 
contributed to the reversal of both prevalence and incidence rates of HIV, donor funded initiatives have overstretched the workforce and the health systems thus diverting healthcare emphases towards specific disease intervention programmes. Evaluation of outcomes measures has consistently excluded viral load assessment, antiretroviral resistant testing and the provision of salvage regimen. Nigeria's budgetary allocation to the health sector is still very low, consequently, government willingness and commitment to the fight against HIV/AIDS is grossly inadequate. The HIV/AIDS programme is still donors dependent and often seen as "donor-agency things". The global aid initiatives have recorded a milestone achievement in the fight against HIV infections in Nigeria. While much is needed from the donor agencies, Nigeria must ensure deliberate commitment towards an independent ownership of HIV/AIDS scheme in Nigeria.

Keywords: Country ownership; foreign aid initiatives; humanistic care; HIV/AIDS; Nigeria.

\section{INTRODUCTION}

Barely two decades after the first case of the human immunodeficiency virus (HIV) infection was identified in the United States of America, has the spread reached a pandemic dimension that attracts global concern. The distribution of the HIV infection has continuously skewed towards sub-Saharan Africa, this region accounts for $70 \%$ of global burden of HIV/AIDS [1,2]. Nigeria has the second highest number of people living with HIV/AIDS worldwide and accounts for $10 \%$ of global HIV/AIDS burden and $20 \%$ of HIV/AIDS burden in Africa [3,1]. Nigeria has an average HIV prevalence rate of $3.1 \%$; a total of 16 States out of the 36 States of the Federation including the Federal Capital Territory (Abuja) had prevalence above $5 \%$ while state average values of $1-12.7 \%$ were recorded. Although, the prevalence was generally higher in urban areas, the highest site prevalence of $21.3 \%$ was reported on a rural settlement and $0.0 \%$ prevalence rates were recorded at four rural communities. The mutual interaction between HIV/AIDS and TB further complicates the epidemiology of both infections. Africa accounts for $24 \%$ of TB burden while Nigeria has a share of $10 \%$ worldwide. HIV/AIDS and TB infections rank as the first and the second leading cause of death respectively from an infectious disease perspective worldwide [4]. In 2011, 1.1 million $(13 \%)$ of the 8.7 million people that developed TB worldwide was HIV-positive and $79 \%$ of these co-infected cohort were in the African region, while Nigeria has a share of $25 \%$ [4].

In response to the HIV pandemic, it became cleared that the developed world must make urgent concerted efforts to halt and reverse the trend of the infection worldwide largely because the scourge affects productivity particularly among those infected and their family members. Global health initiatives (GHI) such as the United
States President's Emergency Program for AIDS Relief (PEPFAR) and the Global Fund to fight AIDS, Tuberculosis and Malaria (GFTAM) etc became vital instruments for the provision of "universal access" to antiretroviral medicines.

Nigeria is recently rated as the strongest economy in Africa based on the output of goods and services; however, its indices based on per capita income and human development indicators are quite disturbing in spite of abundant natural and human endowments. Nigeria would have to collaborate with development agencies for the funding of most of its health intervention policies and programs if the country is to make substantial progress towards meeting health related Sustainable Development Goals (SDGs) by the year 2030. These foreign aid programs are often characterized by a mixture of altruism, hubris and self-interest [5]. With a population growth rate of $2.7 \%$ above the global average of 1.2 , an average total fertility rate of 6.0. [6] combined with high HIV prevalence rates and the overwhelming impact of poverty implies that the country has a high risk of an epidemic explosion; "a country at a threshold". The dynamic of HIV epidemiology where migration influences the narrowing of differentials between urban-rural spread of HIV is already taking its course following the reversal of trends as the highest site prevalence was identified with a rural community in Nigeria.

This article evaluates the influence of foreign aid on the fight against HIV/AIDS in Nigeria and examines the effects of global aid initiatives on the health systems. The study assesses the role and the readiness of the government to independently ensure the ownership and provision of a continuous and sustainable HIV/AIDS care and support in Nigeria. 


\section{COUNTRY PROFILE}

Nigeria has an estimated 182 million people [7]; it is the most populous country in Africa [8]. It is a country with a large multi-ethnic diversity; the population is relatively young, the median age is 18.7 years and about $45 \%$ of the population is under the age of 15 [9]. Unfortunately, Nigeria's health indicators compare with that of poor subSaharan African countries [6].

Life expectancy at birth (years): 54

Neonatal mortality rate (per 1000 live births): 39

Infant mortality rate (probability of dying by age 1 per 1000 live births): 78

Under-5 mortality rate (probability of dying by age 5 per 1000 live births): 124

Maternal mortality ratio (per 100,000 live births): 560

\section{HIV/AIDS AS A DEVELOPMENT AND SECURITY THREAT}

"AIDS is not just a humanitarian crisis. It is a security crisis - because it threatens not just individual citizens, but the very institutions that define and defend the character of a society" [10].

The emergence of foreign aid (global health initiatives) to fight HIV/AIDS was highly applauded worldwide. This concept was adopted as a strategy to achieve the declaration of universal access. However, skeptics argued that such donations were purportedly rendered in fear that the epidemic could undermine both international security and economic development [11]. The potential effect of the epidemic on security and development were affirmed by development and health economists, U. S. Central Intelligence Agency (CIA) and the U. S. Agency for International Development (USAID). These securities and development experts revealed that HIV/AIDS is a security threat; and a humanitarian emergency capable of truncating development, promoting crime and the child soldier phenomenon [11]. It is believed that the nexus of poverty, HIV/AIDS, and alienation from the developed world could foster terrorism. Thus individuals infected with the virus are seen as national threat; this is a repressive approach to the epidemic that is rooted in falsehood [11]. Conversely, Mclnnes and Rushton [12] opined that HIV/AIDS is a national security issue where the referent object is not the individual but the state and/or the international community. Furthermore, Garrett [11] argued that AIDSravaged societies might revolt against perceived discontentment leading to violence with the wealthy nations for neglecting HIV-afflicted States. McGinnis and Sawyer [13] have similar opinion:

"Under extreme conditions of deprivation, desperation, frustration, and anger, citizens result to violence as a form of protest and political contention, voicing their discontent with ineffective institutions and poor living conditions. Public order breaks down as military and police forces are unable to control civil unrest because of their extreme infection rates, thinned out ranks, inexperience, and understaffing. Domestic violence and civil unrest can easily escalate as warlords, criminal gangs, and strongmen enter the power vacuum created by institutional weakness".

As part of its agreement with the U.S. PEPFAR, the government of Nigeria is to contribute at least $50 \%$ of its gross HIV/AIDS budgetary expenditure by 2015 [14]. What happen to the citizens in the event that the development/foreign partners fail to extend this partnership agreement? It is indeed a public health risk, a security and economic risk for a country to rely completely or partly on the developed world for its health. Do we expect the Western world to purchase public health for us to improve our life expectancy? What is the future of people infected with HIV/AIDS in Nigeria? It is high time the HIV/AIDS and to a larger extent the health issues in Nigeria were brought into the political discourse to achieve economic growth. The citizens are gradually beginning to know their rights. Failure to guarantee the provision of sustainable HIV/AIDS care based on the exemption policy might precipitate anarchy and violence that could undermine national security.

HIV/AIDS is an emerging security threat of the $21^{\text {st }}$ century $[15,16]$. HIV is gradually shifting from a health issue to a development crisis [17]. It differs from other life-threatening illnesses because of its devastating impact on morbidity and mortality; more importantly, it selectively affects adult in their most sexually active ages, which correspond with their prime productive years [18]. As the prevalence of AIDS rises, it affects the macroeconomy in two ways: Rising morbidity and rising mortality rates. A rise in morbidity rates results from a negative labour 
productivity and a positive health care expenditure while a rise in mortality causes a negative population growth and a shift in the age structure of the population towards the younger age and the aged [19].

\section{HIV/AIDS AND HUMAN RIGHTS}

"Humanity will not enjoy security without development, it will not enjoy development without security, and it will not enjoy either without respect for human right" [20].

Human rights are inherent in man; they arise from the very nature of man as a social animal [21]. The protection and promotion of human rights is necessary to the protection for the inherent dignity of person infected with HIV and to the attainment of the desired public health goals of reducing and reversing the HIV/AIDS epidemics [22].

PLWHAs have the same fundamental social, cultural, civil, and political human rights as any other person by virtue of their humanity. These rights are universal, indivisible, interdependent, and interrelated [21]. Human rights are not ephemeral, not alterable with time and space and circumstances; they are not the product of philosophical whim or political fashion [23]. The right to privacy of every citizen is enunciated in the Nigerian Constitution of 1999 in S.37. This right is also guaranteed under Article 17 of the International Covenant on Civil and Political Rights (ICCPR); Article 6 of the African Charter on Human and People's Right (ACHPR); Article12 of the UDHR and the International Covenant on Economic, Social and Cultural Rights (ICESCR) [21]. The Nigerian Constitution of 1999, S. 17 (3d) [24] as well as Article 25 of the UDHR guarantee everyone the right to social order-which include the right to access adequate medical and health facilities. Unfortunately PLWHA are often deliberately and out rightly violated [21]. Such deliberate violation could be in terms of omission where the vulnerable groups such as men that have sex with men (MSM) and sex workers are denied of health care services and provisions $[1,25]$.

One of the barriers to reaching those who are infected with HIV/AIDS is stigma [26,27]. Stigma enhances secrecy and denial which are both facilitators of HIV transmission [28]. Stigma is not a singular concept expressed and experienced in a common way; it is a complex phenomenon expressed both subtly and overtly. Stigma is subjectively experienced in multiple ways that are partially depended upon the nature of the stigmatizing condition and the social circumstances of the individual [29]. Stigmatizing and discriminatory attitudes against people living with HIV/AIDS are stronger than that of other diseases [29,30] and occurs within families and other social networks and is often institutionalized [1,31,32].

Stigma undermines ones identity and capacity to cope with the disease and drives HIV positive person out of public sights, while fear of enacted stigma termed discrimination limits the possibility of disclosure [33]. Furthermore, studies have shown that health care practitioners who are trained to render care to PLWHA are themselves prime agents of stigmatization and discrimination $[1,21]$. Nigeria is signatory to various international charters on human rights; however, the practical implementation of such agreements remains a great challenge. The Nigerian citizens are beginning to know their rights as enshrined in the Constitution and certain international charters. In the near future, both the government and the health care workers will be forced using the instrument of law or its obnoxious alternatives such as mass protest, to guarantee their right to equitable access to health care and essential medicines.

In Nigeria, litigations arising from infringement of the rights of PLWHA abound; in its ruling over the termination of appointment of a plaintiff on the bases of her HIV-positive status, the high court of Lagos, Nigeria, pronounced its judgment in favour of the plaintiff $[34,21]$. The judiciary and the civil society must work in concert to promote the health of the people through the use of legal instrument.

\subsection{Nigeria Health System}

"Patients don't read guidelines, and guidelines don't build health systems" [35].

Nigeria has a well-designed national health policy. The national drug policy was designed to fit within the aims and objectives of the national health policy on the background of inadequacies of drug availability, supply and distribution. However, these policies and guidelines are often not in tandem with the realities and actual practice. While it is necessary to have good health and social policy frameworks and guidelines, the implementation of such policy and guidelines require strong political will and 
commitment to equity and social justice. Nigeria's health system is characterized by complexities arising from the federal administrative structures and constitutional provision which classifies health on the concurrent legislative list resulting in parallel but overlapping responsibilities among the three tiers of government thus complicating policy making, regulation and provision of health care [8]. General government expenditure on health as a percentage of total government expenditure has been consistently low (6.7), below the African average of 9.7 and global value of 15.2 [6]. Worse still, portion of this meager budget is often diverted or misappropriated for selfish reasons [8]. Access to and use of quality health care services is also low [14].

\subsection{Budgetary Allocation to the Health System}

Nigeria's expenditure on health has often been below global standards; for instance, total expenditure on health as a percentage of gross domestic products for 2011 is $5.7 \%$ below African average of $6.2 \%$, global average of $6.6 \%$ and the global peak of $14.1 \%$ [6]. Furthermore, per capita government expenditure on health at average exchange rate (US\$) is estimated as $\$ 29$ compared to African average of $\$ 49$, global average of $\$ 472$ and global peak of $\$ 1782$. Consequently, in $2010,50-74 \%$ of HIV/AIDS expenditure in Nigeria was funded by the foreign and development agencies [2].

\subsection{Nigeria Drugs Situation}

In its 1988 evaluation of the world drug situation, WHO classified Nigeria among countries with low health care coverage and in the weakest categories in managing procurement, distribution, information and manpower for essential medicines. Consequently, only $30 \%$ of the population has access to essential medicines [36]. In a keynote address to the Pharmaceutical Society of Nigeria, Tayo, [37] examined the issue of access to medicine in Nigeria and expressed dissatisfaction. The researcher stated that Nigeria is well endowed with both human and natural resources and has no reason to be at this dismal position but for corruption and ineptitude of its leaders. Scarcities of resources to provide health care or to remove causes of disease are often man-made; they seldom happen in the circumstances beyond human control [38]. According to Calabresi and Bobbitt [39] "scarcity is not the result of any absolute lack of a resource but rather of the decision by society that it is not prepared to forgo other goods and benefits of a number sufficient to remove the scarcity". Poor access to medicines is a major feature of most low and middle-income countries $[40,41]$. The drug distribution system in Nigeria has been taken over by charlatans who see drugs as commodities for commerce; consequently, the distribution system is chaotic and disorganized $[42,43]$.

Any country that failed in its responsibility to ensure sustainable provision of essential medicines for its citizens is not likely to guarantee the provision of access to ART medicines. Innovative approaches to ensuring consistent and sustainable provision of essential medicines at country, regional and global level have been shown to reduce cost and improve access to medicines [44]. Pooled procurement of medicines explores this mechanism whereby purchasing is conducted by one procurement office on behalf of a group of facilities, countries or health systems. Such policy increases bargaining power and ensures maximum utilization of scarce resources. The Petroleum (Special) Trust Fund established in 1994 in Nigeria adopted this innovative mechanism to ensure nationwide sustainable access to medicines. The scheme recorded enormous improvement in the availability and affordability of medicines throughout the country [45]. While, this approach was laudably applauded; inefficient management of pooled seed stocks resulted in various form of wastages.

Access to medicine is a public health issue requiring global development policy concern. Today, human rights activist groups are enforcing the explicit reference to access to medicines as a fundamental human rights issue $[37,46]$. The global movement towards the campaign for access to HIV/AIDS medicines and the uprising against the protection of intellectual property for patented drugs especially ART by pharmaceutical companies has brought the issue of access to ART medicines on the international health agenda [37,47]. Access to essential medicines as an essential aspect of the fulfillment of the right to health could be enforced through the courts; this is especially becoming common to low and middle income countries such as Central and Latin America [48]. Human right treaties ratified by governments have fostered the inclusion of the provision of right to health in the constitution which provides the basis of litigations. In Argentina, the international 
human right provision was invoked in the absence of a national constitutional framework for the right to health [48].

\subsection{Nigeria Antiretroviral Drugs Situation: Historical Background}

With an estimated 3.5 million people infected with HIV and a prevalence rate of $5 \%$ in 2002 , Nigeria government initiated the commencement of a programme to provide ART to PLWHA at a subsidized rates for a targeted population of 10,000 adults and 5,000 children annually. At that time, the cost of providing the stavudine based HAART regimen to a patient per month was estimated at \$7.8-11.7 in public facilities while the cost in private facilities ranges from $\$ 54.7-109.4$. Two years later, the programme could not achieve its target of providing access to 20,000 HIV infected person; yet, about $64 \%$ of the meager supply has expired due to inadequacy of the management of essential medicines [49].

\subsection{Effects of Foreign Aid on the Fight against HIV/AIDS in Nigeria}

"From its birth, the campaign against AIDS was much more than a battle against disease. It was a cry for human rights. It was a call for gender equality. It was a fight to end discrimination based on sexual orientation. And it was a demand for the equal treatment of all people" [50].

The scale up of HIV care and treatment services has led to the dramatic expansion of access to ART for PLWHA worldwide [51]. As at 2003, almost all health facilities in Nigeria were without requisite capacity to initiate routine HIV/AIDS care and support programme; subsequent intervention by the federal government to improve access to ART medicines was grossly inadequate and characterized by gross inequities and social injustice [49].

The number of health facilities providing ART care and support in low and middle income countries has risen from 7700 in 2007 to a threefold increase at the end of 2010 . Consequently, an estimated 6.65 million people within these regions were accessing ART compared to 400,000 in 2003 [40,52]. An assessment of the effects of PEPFAR foreign aid on the fight against HIV/AIDS in Nigeria revealed that during the fiscal year 2011, an estimated 414,000 people were receiving ART; while $1,618,300$ HIV positive individuals were undergoing care and support. HIV counseling and testing was done for over 2.3 million people [53].

\subsection{Impact of Foreign Aid on the Health System}

In less than two decades, approximately 100 global health initiatives (GHIs) have been established as a response to meeting the Millennium Development Goals (MDGs). These GHIs explore the public-private partnership mechanisms which mobilized funds channeled into government and the civil society organizations for specific diseases and targeted interventions $[54,55,46]$. While critiques argued that GHIs erode fragile health systems [55] and distorts the national policies of the recipient country [56]. GHls have been shown to have positive interaction with robust health systems possibly due to the human resource capacity to absorb and adapt new programs [57,55,54].

\subsection{Health Services Delivery}

A review of progress made in the fight against HIV/AIDS from 2002-2010 in low-and middle income countries (LMIC) revealed some modest achievement. The percentage of pregnant women tested for HIV increased from $8 \%$ in 2005 to $35 \%$ in 2010 . Furthermore, the number of facilities providing HIV/AIDS care and support programme in LMIC leaped at 7700 to 22400 in three years while the number of people receiving ART has witnessed a geometric achievement with 6,650,000 clients in 2010 compared to 300,000 in 2002 [46]. By the end of September, 2014, PEPFAR provided ART care and support for 7,745,437 people with Nigeria accounting for 610,599 people [52], compared to 13,644 people receiving HAART as at November 2003 [49]. This report further revealed that 140,000 new health workers in PEPFAR supported countries received various trainings on ART care [52].

\subsubsection{Human resource for health}

Inadequate trained health-care personnel at all levels of care in LMIC, and the cost of training and remuneration have persistently been the major obstacle to the provision of care [58]. Before the advent of GHIs for HIV care, most of the health centres in Nigeria lacked basic medical laboratories diagnostics, skills and competence for HIV/TB care [49]. Decentralization of access to ART using the taskshifting principles and the PHC models required that nurses and other health care workers are mobilized to handle roles that were hitherto 
complete preserve of physicians in other to deal with the abysmal health worker shortages $[58,44,59]$. There is also a deliberate effort in the supply of laboratory diagnostics, training for medical staff and financing infrastructural development of healthcare institutions undertaken by development agencies in LMIC including Nigeria [60].

\subsubsection{Health information systems}

While GHIs advocate improvement in the availability and accuracy of data, they tend to focus disproportionately on two dimensions of information: coverage of specific services and surveillance for specific diseases [55]. Inter agencies harmonization of health information system with country based health management system has been a major set-back as GHls often operate a stand-alone disease based information system [55]. Ogungbemi et al. assessed the Nigeria national HIV monitoring and evaluation system; these researchers reported that there were multiple reporting tools for the facility levels that led to a vertical reporting system which increases the burden of reporting to the lower level facilities [61]. This bottom-neck increases the pressure on fragile health systems, imposes pervasive incentive effect that encourages selective reporting that reflects expected results $[62,63]$. In spite of the shortcomings, GHIs have improved the availability and quality of data through training.

\subsubsection{Supply management systems: Antiretroviral medicine and laboratory diagnostic commodities}

It is a general knowledge that GHls have contributed immensely to the provision of access to ART medicine in LMICs. GHIs employ efficient global standards pooled procurement mechanisms with improved distribution networks that promote availability of commodities. Furthermore, GHIs employ the exemption policy mechanism on ARTs and anti-tuberculosis medicines. The inventory control mechanisms under the GHIs ensure timely supply of commodities. Commodities are pooled based on innovative quantification procedures which enhance audit trail of commodities, accountability and reduction in the rate and extent of medicines expiration. Rapid scale-up of HIV services in Nigeria is grossly thwarted by procurement and logistic challenges [64].

Point of care diagnostics (POCD) is the mainstay for the rapid upsurge in HIV testing for sub-
Saharan Africa [65]. The decentralization of HIV health care to remote communities became easier through the use of simple, mobile rapid diagnostics chips $[66,67,68]$. These innovative laboratory techniques available as rapid, easy to use, affordable, cost-effective devices which offer comparative sensitivity and specificity are gradually replacing the regional based traditional but expensive laboratory techniques employed in HIV/TB care $[69,70]$.

\subsubsection{Governance}

Governance is the most complex but critical function of the health system. It is one of the most difficult functions to measure because of the difficulties in definition and measurement [55]. Increase funding without effective monitoring framework of both country level and donor agencies will not achieve the anticipated outcomes. Interaction between donor agencies and health systems governance: coordination and planning structures; coordination and planning processes; and community participation must be seen to promote alignment which prevents duplication in planning for HIV/AIDS control between Country Co-ordination Mechanism (CCM) and national AIDS program $[55,56]$.

\subsubsection{Financing}

Concern about the limited capacity of donor recipient countries to meet global funds conditions for performance-based disbursement and the delays in disbursement of funds impede rapid financing of health intervention [71]. Health care financing at country level has been incapacitated due to inadequate budgetary allocation. Inadequate coordination of funds exemplified by parallel fund inflows and ineffective control mechanisms to guarantee audit trail of inflows and outflows; lack of financial transparency, and inadequate political and financial commitment such as failure of government agencies to commit $1 \%$ of their budgetary allocation to HIV/AIDS as nationally approved [64]. Consequently, the HIV/AIDS national response is invariably donors driven and donor dependent [64]. This situation poses danger for sustainability.

\subsection{HIV/AIDS Outcomes}

\subsubsection{Morbidity: Opportunistic infections, adverse drug reactions, ART resistance}

The use of HAART in patients infected with HIV reduces morbidity and mortality and often results 
in substantial immunological recovery [72]. Evaluation of treatment outcomes is of paramount important; viral load, immunological and resistant testing is critical aspect of care that must be provided to HIV positive patients on ART. While the national guidelines on the use of ART stipulate criteria for the initiation of ART, compliance to these guidelines and recommendations has been a great challenge. In Nairobi, Kenya, a study revealed that none of the 93 patients on HAART had a documented calculated creatinine clearance ( $\mathrm{CrCL})$ on which their ART dosing was based on [73]. Furthermore, $7.7 \%$ of the patients had $\mathrm{CrCL}<50$ $\mathrm{mls} / \mathrm{min}$, reflecting the fraction of patients that require tenofovir dose adjustment. Tenofovir is a potent antiretroviral agent but has been associated with renal failure. Furthermore, recent study in Nigeria, found that none of the 312 patients on HAART who participated in a survey had documented $\mathrm{CrCL}$, and viral load assessment [74]. These researchers opined that critical evaluation of care must not be based exclusively on physical evaluation or clients' perception concerning their health or wellness, though these parameters are necessary; therapeutic indicators must include routine virological, immunological and adverse drug reactions (ADRs) evaluations in order to prevent actual or potential drug therapy problem.

In North America, a retrospective evaluation of antiretroviral drugs resistance to patients recently infected with HIV revealed a spectrum of varying forms of resistance. Over the five-year period,
1995-2000; the frequency of transmission of drug resistance increases significantly [75]. This is consistent with the findings of Gupta et al. [76] who reported statistical increase in the prevalence of antiretroviral resistance over time since ART rollout in sub-Saharan Africa. Drug resistance mutations associated with nonnucleoside reverse transcriptase inhibitors (NNRTIs) were the commonest especially in the regions of East and South Africa probably, due to widespread use of NNRTIs as part of standard first-line ART as well as single-dose nevirapine for prevention of mother-to-child transmission (PMTCT) [77]. Resistance to antiretroviral therapy increases to $30 \%$ per year in East Africa and $14 \%$ per year in South Africa while West and Central Africa, Latin America and the Caribbean reported no variation over time [76]. Although, South Africa has incorporated routine viral loads testing for its national ART program [77]; resistance testing, routine viral loads assessment are not fully captured as a priority in developing countries due to cost implication. Thus, drugs resistance will predictably emerge as another threat to antiretroviral treatment for developing countries [78].

Furthermore, resistance to antiretroviral therapy is increasingly seen among early diagnosed HIVnaïve patients including children on ART and HIV-naïve children. In Brazil, drug resistance was identified with 47 children in a hospital in Sao Paulo and more than $50 \%$ of them have already developed resistance before initiation of therapy [79].

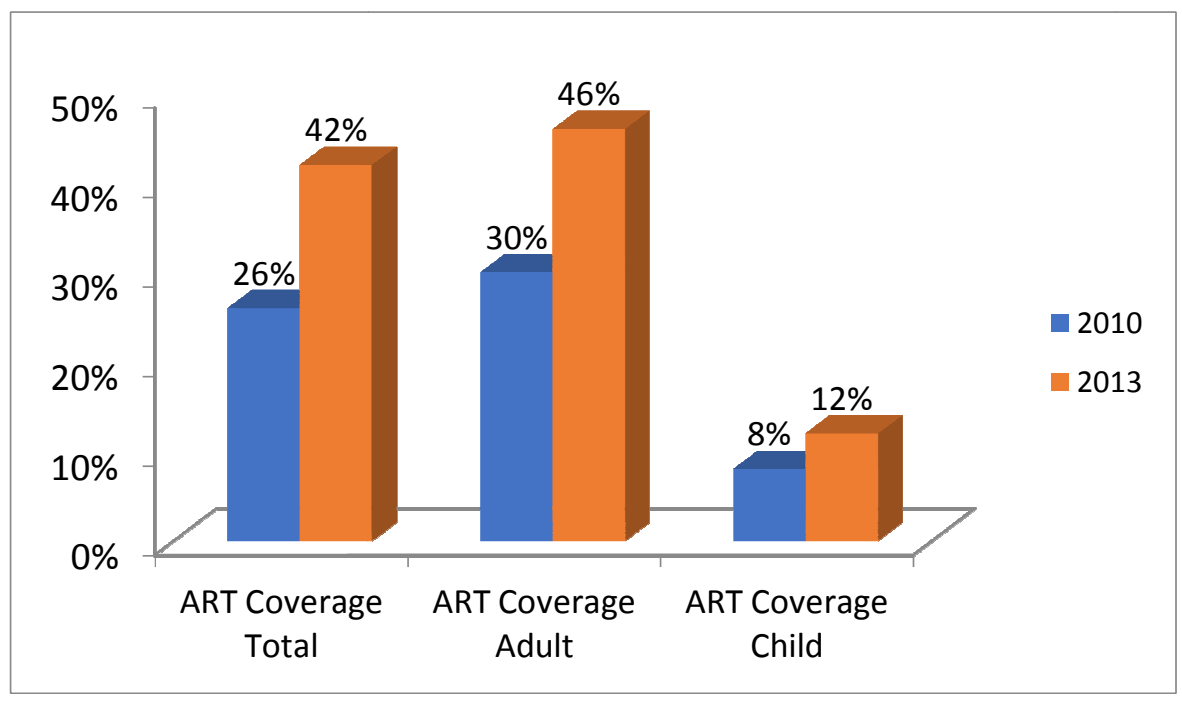

Fig. 1. ART Coverage: 2010 vs. 2013 (NACA, 2012) 
Nigeria has a high burden of both HIV and TB infections with an average HIV/TB co-infection prevalence of $25 \%$ [80] above the global average of $13 \%$ [4]. While both diseases are among the leading causes of death from an infectious perspective, the mutual interaction between TB and HIV/AIDS worsens disease progression, increases the chances of TB re-infection [81] and complicates TB diagnosis. Furthermore, the emergence of multi-drug resistance TB (MDRTB) and extensive drug resistance TB (EDR-TB) underscore the need for culture and drug sensitivity testing (DST) laboratory diagnostics. At present, Nigeria has only four functional laboratories for cultures and drug sensitivity testing for the country [80]. This is grossly inadequate for a country that pride itself as the most populous country in Africa as well as the most populous black nation in the world. Furthermore, Nigeria is one of the countries with the highest burden of both HIV and TB in the world; government must show commitment in eradicating HIV and TB.

\subsubsection{Mortality}

The advent of HAART and the subsequent introduction of the protease inhibitors have changed the mortality and morbidity that once mystified HIV/AIDS as "a death sentence" to what is now known as a chronic disease $[72,82]$. In 2010, a report indicated that about 3.1 million people in Nigeria were infected with HIV while an estimated 215,000 HIV related deaths was recorded [7]. The reduction in mortality rate has socio-economic implications as attendant consequences such as loss of "bread winners" and "orphaned children" have been minimized.

\subsubsection{HIV incidence}

Nigeria has witnessed a moderate decline of $54 \%$, from $0.46 \%$ in 2003 to $0.21 \%$ in 2013 in the incidence rate of HIV. Within this period, the number of people with new infection declined from 348,564 to 220,394 , which represent $37 \%$ reduction. Compared to the top ten countries worse infected with HIV in sub-Saharan Africa, Nigeria ranked the fifth in terms of decreasing numbers of new infection. If the declining trend as depicted in Fig. 2 is sustained, there is the tendency that the nation will turn to be one of the least infected nations not only in sub-Saharan Africa but in the continent and indeed in the world. This indeed is necessary as one of the steps in the nation's quests towards achieving Sustainable Development Goal Three (3).

\subsubsection{HIV prevalence}

The estimated adult HIV prevalence in Nigeria has dropped from $3.70 \%$ in 2003 to $3.20 \%$ in 2013 , a decline rate of $14 \%$. The prevalence among pregnant women 15-24 years-old has witnessed $33.3 \%$ reduction in a period of ten years, from 6.0 in 2001 to 4.1 in 2010. This declining trend in the scourge which hitherto ravaged the productivity of the labour force in the country implies a healthier productive labour force which is capable of ensuring sustainable economic growth all things being equal.

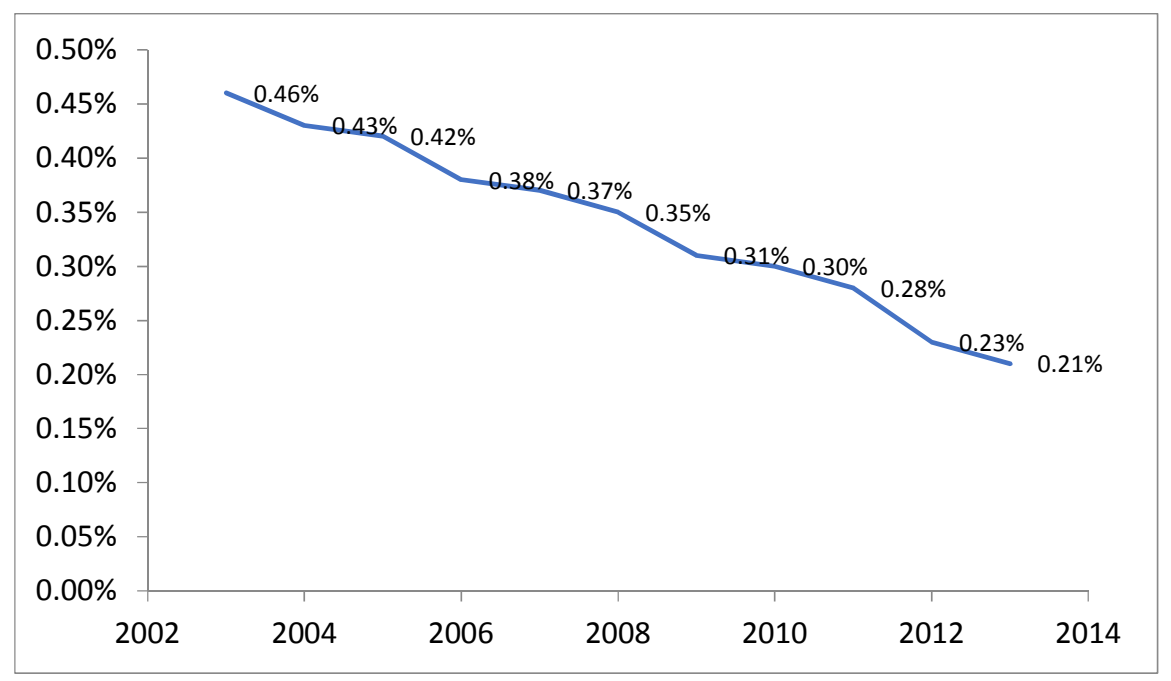

Fig. 2. Estimate incidence of HIV in Nigeria 2003-2013: A 54\% reduction (NACA, 2010) 


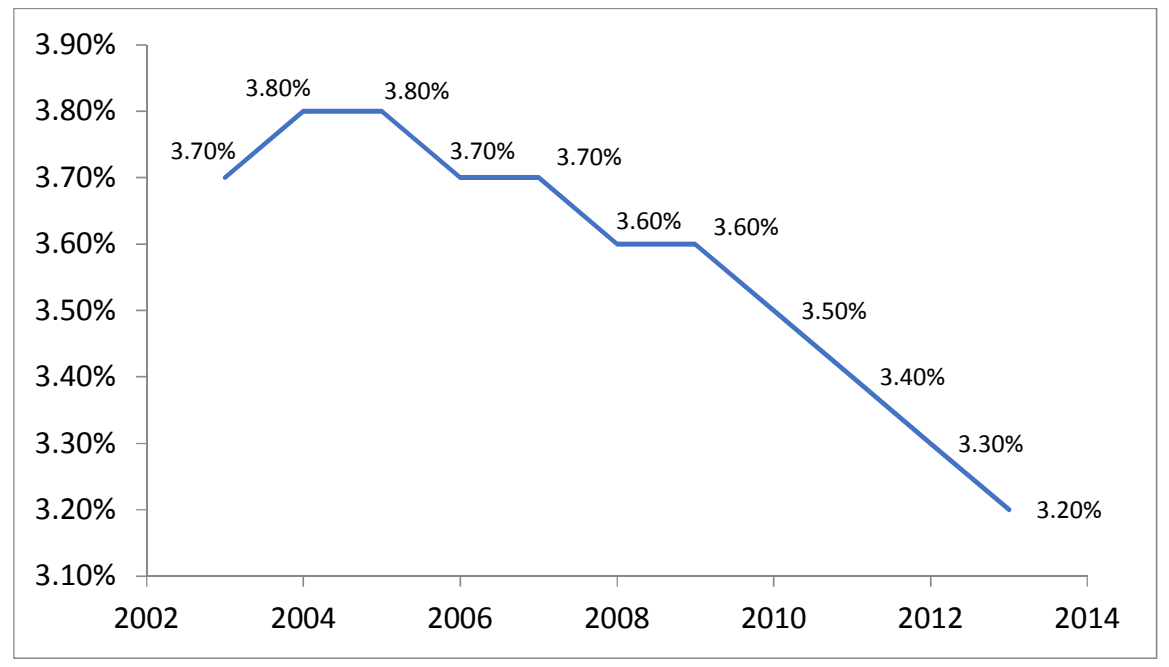

Fig. 3. Estimate adult HIV prevalence: 2003-2013 (NACA, 2010)

\section{CONCLUSION}

Global Health Initiatives has greatly improved the provision of access to antiretroviral medicines in Nigeria. While it can be argued that it has overstretched the health work force thus diverting health care services towards disease specific programmes, its impact on the country health systems is huge. Nigeria has recorded a downward trend in both the incidence and prevalence of HIV infection through the continuous support received from development partners. The morbidity and mortality due to HIV/AIDS have declined. However, the aspect of humanistic outcomes deserves critical concern. The programme often neglects some important outcome measures such as the percentage of clients that accessed viral load investigations at specified time frames, assessing the level of ART resistance and monitoring patients for emergence of ADRs. Government contribution to the health sector is very poor. Meanwhile, the HIV/AIDS programme is invariably donors driven and donor dependent. Thus, any sudden delay in foreign funding may have catastrophic effects on the health systems and the health of people living with HIV/AIDS.

\section{CONSENT}

It is not applicable.

\section{ETHICAL APPROVAL}

It is not applicable.

\section{COMPETING INTERESTS}

Authors have declared that no competing interests exist.

\section{REFERENCES}

1. UNAIDS. Reports on the global AIDS epidemic. 2008;16:30-33,76-77,89.

Available:www.data.unaids.org/pun/report/ 2006/20061101-pbcsecurity

2. UNAIDS. UNAIDS Report on Global AIDS Epidemics. 2013;4:74.

Availableat:www.unaids.org/--Igr2013/UNAIDS Global Report 2013 en .pdf

(Accessed 3/1/2015)

3. Federal Ministry of Health (FMOH). National HIV sero-prevalence sentinels survey: Technical report. Abuja. 2010;5152.

4. World Health Organization. Global tuberculosis report. 2012;1-3,36-49,74-76.

5. Green D. From poverty to power. Oxford, Oxfam publishing. 2008;363.

6. World Health Organization. World health statistics. 2014;59-69,141-175.

7. NACA. National HIV/AIDS Response fact sheet 2011; update on HIV/AIDS epidemic and response in Nigeria; 2012.

Available:www.naca.gov.ng/

8. Gilbert K, Fleisher L, Kariisa E, Arur A, Sanjana $P$, Paina $L$, et al. Nigeria health system assessment 2008. Abt Associates Inc. 2009;1-2,6-8,11. 
9. Gore A. Vice president's remarks to UN security council session on AIDS; 2000; Available:www.clinton4.nara.gov/ONAP/pu b/vp un sc.html (Accessed: 3/2/2015)

10. Nattrass N. U.S. foreign aid and the African AIDS epidemic. Yale Journal of International Affairs. 2013;52-61.

11. Garrett L. HIV and national security: Where are the links?; 2005.

Available:www.cfr.org/--lattachments/HIV National Security.pdf. (Cited: 5/1/2015)

12. Mclnnes C, Rushton S. HIV/AIDS and securitization theory. European Journal of International Relations. 2013;19(1):115138.

13. McGinnis, Sawyer. HIV/AIDS, State Capacity, and Security in Africa. A paper presented at the workshop and political theory and policy analysis, Indiana University Mini Conference; 2003.

Available:www.indiana.edu/ workshop/se minars/papers/y673 spring

(Cited: 9/1/2015)

14. PEPFAR. Partnership framework on HIV/AIDS, 2010-2015: A memorandum ofunderstanding between the Government of Nigeria and the United States government to fight HIV/AIDS in Nigeria; 2010.

Available:www.pepfar.gov/documents/orga nization/148812.pdf

(Cited: 06/01/2015)

15. Adesina OS. HIV/AIDS as a Threat to Nigeria's national security. International Journal of Business and Social Science. 2014;5(1):231-240.

16. Feldbaum $\mathrm{H}$, Lee $\mathrm{K}$, Patel $\mathrm{P}$. The national security implications of HIV/AIDS. PLoS Medicine. 2006;3(6):0774-779. e171

17. UNAIDS. Meeting on the international partnership against HIV/AIDS in Africa; 1999.

18. Armstrong J. Uganda's AIDS crisis: Its implications for development. Washington, World Bank. 1995;37.

19. Cuddington JT. Modeling the microeconomic effects of AIDS, with an application to Tanzania. The World Bank economic review. 1993;7(2):173-189.

20. Annan K. In larger freedom: Towards development, security and human rights for all; 2005.

Available:www.un.org/en/events/pastevent s/in larger freedom.shtml.

(Cited: 3/2/2015)
21. Centre for the right to health for the policy $(\mathrm{CRH})$. HIV/AIDS and human rights in Nigeria: Background paper for HIV/AIDS policy review in Nigeria; 2003.

Available:www.usaid.gov/pdfdocs/PNACX553.pdf

(Cited: 04/10/2011)

22. UNAIDS. International guidelines on HIV/AIDS and human rights: Consolidated version; 2006.

23. Bhagwati PN. Creating a Judicial Culture to promote the enforcement of Women's Human Rights. In Advancing the Human Rights of Women: Using human rights standard in civil litigation. Hong Kong. 1996;21.

24. Federal Republic of Nigeria. Constitution of the Federal Republic of Nigeria. Lagos; Federal Government Press: 1999;12:2223.

25. Amon JJ, Baral SD, Beyrer C, Kass N. Human rights research and ethics review: Protecting individuals or protecting the state? PLOS Medicine. 2012;9(10):1-5. e1001325.

26. Monjok E, Smesny A, Essien EJ. HIV/AIDS -Related Stigma and Discrimination in Nigeria: Review of research studies and future directions for Prevention Strategies. Afr J Reprod Health. 2009;13(3):21-35.

27. Deacon H. Towards a sustainable theory of health related stigma: Lessons from the HIV/AIDS literature. Journal of Community and Applied Social Psychology. 2006;16: 418-425.

28. Rankin WW, Brennan S, Schell E, Laviwa J, Rankin SH. The Stigma of Being HIVPositive in Africa: HIV-related stigma is fueling the epidemic, and disempowering women even further. PLoS Medicine. 2005;(2):8e247:702-704.

29. Fife BL, Wright ER. Dimensionality of stigma: A comparison of its impact on the self of persons with HIV/AIDS and cancer. $J$ Health and Soc Behaviour. 2000;41(1): 50-67.

30. Lau JTF, Tsui HY. Comparing the magnitude of discriminatory attitudes toward people living with HIV/AIDS and toward people with mental illness in the Hong Konggeneral population. Health Education Research. 2007;22(1):139-152.

31. Adeokun LA, Ladipo OA, Odutolu O. Bridging the knowledge-behaviour gap through HIV/AIDS surveillance in four 
markets in Ogbomosho and Ibadan, Nigeria. Archives of Ibadan Medicine. 2004;5:59-65.

32. Muoghalu CO, Jegede SA. Perception of HIV/AIDS among the Igbo of Anambra State, Nigeria. Journal of Social Aspects of HIV/AIDS. 2013;10(1):42-54.

33. Skinner D, Mfecane S. Stigma, discrimination and the implications for people living with HIV/AIDS in South Africa. Journal of Social Aspects of HIV/AIDS. 2004;1(3):157-164.

34. Global Health Rights (GHR). Global health and human rights database. 2015; Available:at:www.globalhealthrights.org/cat egory/africa/nigeria

(Cited: 02/02/2015)

35. De-Cock KM. HIV/AIDS will remain a major challenge in global health for decades to come: "State of the HIV universe". A keynote address. Africa Health. 2009;31 (6):18-21.

36. World Health Organization. World Drug Situation. Geneva. 1988;1-55.

37. Tayo F. Access to safe medicines: A human right. Keynote address at the World Pharmacists Day event organized by the Pharmaceutical Society of Nigeria in collaboration with the National Human Rights Commission September 25, 2012. West African Journal of Pharmacy. 2013; 24(1):1-12

38. Schrecker T. Denaturalizing scarcity: A strategy of enquiry for public health ethics. Bulletin of the World Health Organization. 2008;88:600-605.

39. Calabresi G, Bobbitt P. Tragic choices. New York: WW Norton. 1978;22:150-151.

40. World Health Organization. World medicines situation; 2011b.

Available:www.who.int/medicines/areas/pol icy/world medicines situation/en/

41. WHO. Using indicators to measure country pharmaceutical situations: Fact book on WHO level I and level II monitoring indicators. Geneva; WHO publications. 2006;33-34.

42. Eniojukan JF, Tijani MM, Aina BA. Drug distribution networks in Nigeria. Nigerian Quarterly Journal of Hospital Medicine. 1997; 7:384-385.

43. Jallow MT. Sustainable access to medicine for diseases of public health concern in the West African Sub-Region. West African Journal of Pharmacy. 2007;20(1):2-3.

44. WHO. Multi-country regional pooled procurement of medicines: Identifying key principles for enabling regional pooled procurement and a framework for inter-regional collaboration in the African Caribbean and Pacific Island countries. Meeting report. Geneva: WHO publications: 2007;9,15-19.

45. Tayo F. Petroleum (Special) Trust Fund intervention and sustainability of the drug revolving fund. West African Journal Pharmacy. 1998;12(2):56-60.

46. WHO, UNAIDS and UNICEF. Global HIV/AIDS response: Epidemic update and health sector progress towards universal access: Progress report. 2011;2-3.

47. Beran D, McCabe A, Yudkin JS. Access to medicines versus access to treatment: the case of type 1 diabetes. Bulletin of the World Health Organization. 2008;86(8): 648-9.

48. Hogerzeil HV. Essential medicines and human rights: What can they learn from each other? Bulletin of the World Health Organization. 2006;84:371-375.

49. Federal Ministry of Health/World Health Organization. Situation of antiretroviral drug use in Nigeria; 2003.

Available:www.apps.who.int/medicinedocs/ en/m/documents/s16455e/s16455e (Cited:13/12/2014)

50. Moon B. United Nations Secretary-General remarks to General Assembly high-level meeting on HIV/AIDS. New York; 2011. Available:http://www2.ohchr.org/english/bo dies/hrcouncil/docs/19session/A.HRC.19.3 7 en.pdf

51. El-Sadr WM, Holmes CB, Mugyenyi $P$, Thirumurthy $H$, Ellerbrock $T$, Ferris $R$, et al. Scale-up of HIV treatment through PEPFER: A historic public health achievement. Acquir Immune Defic Syndr. 2012;60Suppl 3:S96-104.

52. PEPFAR. Shared responsibilitystrengthening results for an AIDS-free generation: latest PEPFARfunding. 2014a; Availableat:www.pepfar.gov/documents/or ganization/189671.pdf (Cited: 6/1/2015)

53. PEPFAR. Partnership to fight HIV/AIDS in Nigeria; 2012.

Available:www.pepfar.gov/documents/orga nization/199599.pdf

(Cited: 6/1/2015)

54. Warren AE, Wyss K, Shakarishvili G, Atun $R$, de Savigny $D$. Global health initiative investments and health systems strengthening: A content analysis of global 
fund investments. Globalization and Health. 2013;9:30.

Available:www.globalizationandhealth.com /content/9/1/30

(Cited: 18/04/2015)

55. Samb B, et al. An assessment of interactions between global health initiatives and country health systems. Lancet. 2009;373:2137-69.

56. Biesma RG, Brugha R, Harmer A, Walsh A, Spicer $N$ and Walt $G$. The effects of global health initiatives on country health systems: A review of the evidence from HIV/AIDS control. Health Policy and Planning. 2009;24:239-252.

57. Cavalli A, Bamba SI, Traore MN, Boelaert $M$, Coulibaly $\mathrm{Y}$, Polman $\mathrm{K}$, et al. Interactions between global health initiatives and country health systems: The case of a neglected tropical diseases control program in Mali. PLoS Negl Trop Dis. 2010;4(8):e798.

58. Bartlett JA, Shao JF. Success, challenges, and limitations of current antiretroviral therapy in low-income and middle-income countries. Lancet Infect Dis. 2009;9:63749.

59. Morris MB, Chapula BT, Chi BH, Mwango A, Chi HF, Mwanza J, Manda H, Bolton C, Pankratz DS, Stringer JSA, Reid SE. Use of task-shifting to rapidly scale-up HIV treatment services: Experiences from Lusaka, Zambia. BMC Health Services Research. 2009;9:5.

DOI: 10.1186/1472-6963-9-5

60. PEPFAR. Health systems strengthening; 2009.

Available:line:www.pepfar.gov/about/strate gy/ghi/134854.htm

(Cited: 18/04/2015)

61. Ogungbemin K, Oyediran KA, Mullen S, LaFond A, Azeez A, Boone D, et al. Using UNAIDS's organizing framework to assess Nigeria's national HIV monitoring and evaluation system. Open Journal of Preventive Medicine. 2012;2(3):372-378.

62. Evans T, Stansfield S. Health information in the new millennium: A gathering storm? Bulletin of the World Health Organization, Editorials. 2003;81(12):856.

63. Bennett S, Boerma JT, Brugha R. Scaling up HIV/AIDS evaluation. Lancet. 2006; 367:79-82.

64. National Agency for the Control of AIDS (NACA). National HIV/AIDS strategic plan 2010-2015. 2010.
Available:www.aidstarone.com/sites/defaul t/files/preventionresources/nationalstrategi c-plans/Nigeria2010-15pdf.

(Cited: 27/05/2015)

65. Pai NP, Peeling RW, Smith BD, Dowdy D. Point-of-care tests for HIV, related coinfections, and blood-borne infections. AIDS Research and Treatment [editorial]. 2014;2014, Article ID 625082.

Available:http://dx.doi.org/10.1155/2014/62 5082

(Cited 2/1/2015)

66. Aleku GA, Adoga MP, Agwale SM. HIV point-of-care diagnostics: Meeting the special needs of sub-Saharan Africa. J Infect Dev Ctries. 2014;8(10):1231-1243.

Available:http://dx.doi:10.3855/jidc.4664

(Cited: 3/1/2015)

67. Setty MKHG, Hewlett IK. Point of care technologies for HIV. AIDS research and treatment. 2014;2014, Article ID 497046. Available:http://dx.doi.org/10.1155/2014/49 7046

68. Langford SE, Ananworanich J, Cooper DA. Predictors of disease progression in HIV infection: A review. AIDS Research and Therapy. 2007;4:11.

Available:http://www.aidsrestherapy.com/c ontent/4/1/11 (Cited: $2 / 1 / 2015$ )

69. Moore DAJ, Mendoza D, Gilman $\mathrm{RH}$, Evans CAW, Delgado MGH, Jose Guerra J. et al. Tuberculosis working group in Peru. Microscopic observation drug susceptibility assay, a rapid, reliable diagnostic test for multidrug-resistant tuberculosis suitable for use in resourcepoor settings. Journal of Clinical Microbiology. 2004;42(10):4432-4437.

70. Minion J, Pai M. Expanding the role of the microscopic observation drug susceptibility assay in tuberculosis and HIV management. Clinical Infectious Diseases [editorial]. 2010;50:997-999.

71. Brugha $R$, Donoghue $M$, Starling $M$, Ndubani P, Ssengooba F, Fernandes B, Walt G. The global Fund: managing great expectations. The Lancet. 2004;364:95100.

72. Palella FJ Jr, Delaney KM, Moorman AC et al. Declining morbidity and mortality among patients with advanced human immunodeficiency virus infection. $\mathrm{N}$ Engl J Med. 1998;338:853-60.

73. Shavadia J, Tesfaldet G, Twahir M. Antiretroviral therapy dose adjustments based on calculated creatinine clearance. 
East African Medical Journal. 2009;86(4): 186-189.

74. Joseph BN, Wannang NN, Dangiwa AD Dapar MP. The economic, psychosocial burden and state ownership of HIV/AIDS program in Nasarawa State, Nigeria. West African Journal of Pharmacy. 2014;25(2): 125-136.

75. Little SJ, Holte S, Routy JP, Daar ES, Markowitz M, Collier AC, et al. Antiretroviral-drug resistance among patients recently infected with HIV. N Engl J Med. 2002;347(6):385-94.

76. Gupta RK, Jordan MR, Sultan BJ, Hill A, Davis DHJ, Gregson J. Global trends in antiretroviral resistance in treatment-naïve individuals with HIV after rollout of antiretroviral treatment in resource-limited settings: A global collaboratve study and meta-regression analysis. Lancet. 2012; 380:1250-58.

77. Hamers RL, Wallis C, Kityo C, Siwale M, Mandaliya K, Conradie F. HIV-1 drug resistance in antiretroviral-naïve individualsin sub-Saharan Africa after rollout of antiretroviral therapy: A multicentre observational study. Lancet Infect Dis. 2011;11:750-59.
78. Hirsch MS, Günthard HF, Schapiro JM, Brun-Vézinet F, Clotet B, Hammer SM. Antiretroviral drug resistance testing in adult HIV-1 infection: 2008 recommendations of an international AIDS society- USA Panel. Clinical Infectious Diseases. 2008;47:266-85.

79. Almeida FJ, Berezin EN, Rodrigues R, Safadi MA, Arnoni MV, Oliveira C. et al. Diversity and prevalence of antiretroviral genotypic resistance mutations among HIV-1-infected children. J Pediatr (Rio J). 2009;85(2):104-9.

80. US Embassy in Nigeria. Nigeria tuberculosis fact sheet; 2012.

Available:www.nigeria.usembassy.gov

81. Narayanan S, Swaminathan S, Supply P, Shanmugam S, Narendra G, Hari L, et al. Impact of HIV infection on the recurrence of tuberculosis in South India. Journal of Infectious Diseases. 2010;201:691-701. Availableat:www.jid.oxfordjournals.org/ (Accessed:19 February 2013)

82. Mocroft A, Vella S, Benfield TL, Chest A, Miller V, Gargalianos P. et al. Changing patterns of mortality across Europe in patients infected with HIV-1. The Lancet. 1998;352:1725-30.

(0) 2017 Joseph et al.; This is an Open Access article distributed under the terms of the Creative Commons Attribution License (http://creativecommons.org/licenses/by/4.0), which permits unrestricted use, distribution, and reproduction in any medium, provided the original work is properly cited.

Peer-review history:

The peer review history for this paper can be accessed here: http://sciencedomain.org/review-history19626 